〔日農医誌 39巻 1 号 36 38頁１990．5〕

資料：

\title{
アルコール性肝障害症例における 末梢血所見の検討
}

\author{
森 本 哲 雄, 岡 崎 幸 紀, 水田 実*
}

人間ドック症例を対照群として慢性肝炎, アルコール性肝障害（肝機能検査值によって 2 群に分 類した）症例の末梢血所見を比較検討した。その結果, 慢性肝炎で有意差を認めた項目は血小板数 のみであった。アルコール性肝障害で有意差を認めた項目は, 赤血球数, $\mathrm{MCV}, \mathrm{MCH}$, 好中球な どであった。 MCV と肝機能検査各項目との相関関係を検討すると, 人間ドックおよび慢性肝炎では $\mathrm{MCV}$ と有意の相関を認めた項目は皆無であった。アルコール性肝障害ではGOT/GPT (OP 比), $\mathrm{LDH}, \mathrm{CHE} の 3$ 項目に有意の相関を認めた。

\section{(1)末梢血所見 (2)人間ドック (3)慢性肝炎 (4)アルコール性肝障害 (5) MCV}

\section{I 緒言}

慢性肝疾患症例の多くには貧血が認められる。その 原因として食道静脈瘤や胃・十二指腸潰瘍からの出血, 葉酸欠乏，脾機能六進による赤血球破壊などが考兄ら れている。アルコール性肝障害症例の多くには巨赤芽 球性貧血が認められるが，その原因は葉酸欠乏による ものといわれている。今回筆者はアルコール性肝障害 症例を中心として, 慢性肝疾患症例に括ける末梢血所 見の変化を比較検討したので報告する。

\section{II 研 究 方 法}

研究対象はすべて当院への男性入院患者である。対 象を 4 群に分類して検討した。まず(1)対照群として人 間ドック症例のらち, $\mathrm{HB}_{\mathrm{s}}$ 抗原陰性, 1 日领酒量 1 合 未満で, 肝機能検査値正常例を用いた。(2)慢性肝炎症 例は $\mathrm{HB}_{\mathrm{s}}$ 抗原陰性で领酒歷がなく，長期にわたり肝機 能検査値異常が持続している症例で, 腹腔鏡肝生検, 腹部超音波検査拈よびC Tによって慢性肝炎と診断さ れている。

アルコール性肝障害の診断基準については, 武内 ら 1の詳細な報告があり組織所見が重要な診断根拠と されている。筆者は武内らの報告を参考としながら， しかし組織所見ではなく臨床所見のみによって以下の

* 周東総合病院内科

（受付：1989年11月22日）
ごとく分類した。まず(3)アルコール肝 $\mathrm{a}$ とは「常習飲 酒家」1)であって肝機能異常を認めるが，入院時の GOT 拉よび GPT 值が 100 単位未満の症例である。つ ぎに(4)アルコール肝 b とは「常習飲酒家」であって, 入院時 GOT または GPT 值が 100 単位以上の症例で ある。いずれの症例も腹部超音波検查およびC T よって肝硬変症は否定されている。また $\mathrm{HB}_{\mathrm{s}}$ 抗原は陰 性であった。

なおすべての值の有意差検定は Student一 $\mathrm{t}$ 検定で 行なった。

$$
\text { III 成 }
$$

表 1 に各群の末梢血所見（平均値）を示した。また 表 2 には肝機能検查值 (平均値)を示した。人間ドッ クを対照群として各群との比較を行なった。表 3 に末 梢血所見の検定結果を示す。それによれば慢性肝炎で 有意差を認めた項目は血小板数のみであった。一方, アルコール肝 $\mathrm{a}$ 打よびアルコール肝 $\mathrm{b}$ に共通して有意 差を認めた項目は, 赤血球数, $\mathrm{MCV}, \mathrm{MCH}$, 好中球, リンパ球であった。またアルコール肝 bではへモグロ ビン，血小板数でも有意差が見られた。

表 4 に肝機能検查値の検定結果を示す。ほとんどの 項目で有意差を認めたが, ZTT は慢性肝炎でのみ有意 差があり, アルコール肝 $\mathrm{a}$ 拈よびアルコール肝 bでは 有意差が無かった。

最後に, MCV と肝機能検査各項目との相関関係を 検討した(表 5 )。その結果, 人間ドックおよび慢性肝 
表 1. 各群の末梢血所見 (平均値)

\begin{tabular}{|c|c|c|c|c|c|}
\hline & & $\begin{array}{c}\text { 人 間 } \\
\text { ドック }\end{array}$ & $\begin{array}{l}\text { 慢 性 } \\
\text { 肝 炎 }\end{array}$ & $\begin{array}{l}\text { アルコール } \\
\text { 肝 } \mathrm{a}\end{array}$ & $\begin{array}{l}\text { アルコール } \\
\text { 肝 b }\end{array}$ \\
\hline \multicolumn{2}{|l|}{ 症 例 数 } & 24 & 22 & 20 & 20 \\
\hline \multicolumn{2}{|l|}{ 年 令 } & 48.4 & 49.4 & 49.3 & 49.2 \\
\hline WBC & $\left(/ \mathrm{mm}^{3}\right)$ & 6017 & 5336 & 7425 & 6740 \\
\hline \multicolumn{2}{|c|}{$\operatorname{RBC}\left(\times 10^{4} / \mathrm{mm}^{3}\right)$} & 471 & 460 & 427 & 416 \\
\hline $\mathrm{Hb}$ & $(\mathrm{g} / \mathrm{dl})$ & 15.1 & 15.1 & 14.5 & 14.4 \\
\hline $\mathrm{Ht}$ & $(\%)$ & 43.4 & 43.8 & 42.2 & 42.0 \\
\hline $\mathrm{MCV}$ & (fl) & 92.2 & 95.3 & 99.5 & 101.0 \\
\hline $\mathrm{MCH}$ & $(\mathrm{Pg})$ & 32.0 & 32.9 & 34.2 & 34.6 \\
\hline $\mathrm{MCHC}$ & $(\%)$ & 34.7 & 34.5 & 34.3 & 34.3 \\
\hline Plt $\quad(x$ & $\left.0^{4} / \mathrm{mm}^{3}\right)$ & 24.5 & 17.4 & 22.8 & 16.4 \\
\hline Seg & $(\%)$ & 47.0 & 42.3 & 53.4 & 58.0 \\
\hline Mono & $(\%)$ & 5.6 & 7.7 & 7.0 & 6.6 \\
\hline Ly & $(\%)$ & 40.0 & 42.0 & 30.2 & 26.3 \\
\hline
\end{tabular}

表 3 . 末梢血所見の検定結果

(対照群：人間ドック)

\begin{tabular}{l|c|c|c}
\hline & 慢性肝炎 & アルコール肝 $\mathbf{a}$ & アルコール肝 $\mathbf{b}$ \\
\hline 年 令 & $\mathrm{NS}$ & $\mathrm{NS}$ & $\mathrm{NS}$ \\
$\mathrm{WBC}$ & $\mathrm{NS}$ & $\mathrm{NS}$ & $\mathrm{NS}$ \\
$\mathrm{RBC}$ & $\mathrm{NS}$ & $\mathrm{p}<0.01$ & $\mathrm{p}<0.01$ \\
$\mathrm{Hb}$ & $\mathrm{NS}$ & $\mathrm{NS}$ & $\mathrm{p}<0.05$ \\
$\mathrm{Ht}$ & $\mathrm{NS}$ & $\mathrm{NS}$ & $\mathrm{NS}$ \\
$\mathrm{MCV}$ & $\mathrm{NS}$ & $\mathrm{p}<0.01$ & $\mathrm{p}<0.01$ \\
$\mathrm{MCH}$ & $\mathrm{NS}$ & $\mathrm{p}<0.01$ & $\mathrm{p}<0.01$ \\
$\mathrm{MCHC}$ & $\mathrm{NS}$ & $\mathrm{NS}$ & $\mathrm{NS}$ \\
$\mathrm{Plt}$ & $\mathrm{p}<0.01$ & $\mathrm{NS}$ & $\mathrm{p}<0.01$ \\
Seg & $\mathrm{NS}$ & $\mathrm{p}<0.01$ & $\mathrm{p}<0.01$ \\
Mono & $\mathrm{NS}$ & $\mathrm{NS}$ & $\mathrm{NS}$ \\
Ly & $\mathrm{NS}$ & $\mathrm{p}<0.01$ & $\mathrm{p}<0.01$
\end{tabular}

表 2. 各群の肝機能検査值（平均値）

\begin{tabular}{|c|c|c|c|c|}
\hline & $\begin{array}{c}\text { 人 間 } \\
\text { ドック }\end{array}$ & $\begin{array}{ll}\text { 慢 性 } \\
\text { 肝 炎 }\end{array}$ & $\begin{array}{l}\text { アルコール } \\
\text { 肝 } \mathrm{a}\end{array}$ & $\begin{array}{l}\text { アルコール } \\
\text { 肝 } \mathrm{b}\end{array}$ \\
\hline ZTT & 8.0 & 15.6 & 8.8 & 10.9 \\
\hline GOT & 16 & 112 & 55 & 322 \\
\hline GPT & 14 & 191 & 53 & 137 \\
\hline OP 比 & 1.3 & 0.69 & 1.2 & 2.4 \\
\hline LDH & 243 & 268 & 303 & 514 \\
\hline ALP & 6.7 & 9.8 & 7.4 & 12.8 \\
\hline$\gamma-\mathrm{GTP} \quad(\mathrm{U})$ & 24 & 178 & 258 & 765 \\
\hline $\mathrm{CHE}(\triangle \mathrm{PH})$ & 0.98 & 0.79 & 0.75 & 0.79 \\
\hline LAP & 166 & 285 & 285 & 494 \\
\hline $\mathrm{T}-\mathrm{B} \quad(\mathrm{mg} / \mathrm{dl})$ & 0.69 & 0.97 & 0.92 & 1.8 \\
\hline ALB $\quad(\mathrm{g} / \mathrm{dl})$ & 4.2 & 3.9 & 3.8 & 3.8 \\
\hline $\mathrm{A} / \mathrm{G}$ & 1.2 & 0.97 & 1.2 & 1.0 \\
\hline
\end{tabular}

表 4 . 肝機能検査所見の検定結果 (対照群：人間ドック)

\begin{tabular}{l|c|c|c}
\hline & 慢性肝炎 & アルコール肝 $\mathrm{a}$ & アルコール肝 $\mathrm{b}$ \\
\hline ZTT & $\mathrm{p}<0.01$ & $\mathrm{NS}$ & $\mathrm{NS}$ \\
GOT & $\mathrm{p}<0.01$ & $\mathrm{p}<0.01$ & $\mathrm{p}<0.01$ \\
GPT & $\mathrm{p}<0.01$ & $\mathrm{p}<0.01$ & $\mathrm{p}<0.01$ \\
OP 比 & $\mathrm{p}<0.01$ & $\mathrm{NS}$ & $\mathrm{p}<0.01$ \\
LDH & $\mathrm{NS}$ & $\mathrm{p}<0.01$ & $\mathrm{p}<0.01$ \\
ALP & $\mathrm{p}<0.01$ & $\mathrm{NS}$ & $\mathrm{p}<0.01$ \\
$\gamma-\mathrm{GTP}$ & $\mathrm{p}<0.01$ & $\mathrm{p}<0.01$ & $\mathrm{p}<0.01$ \\
CHE & $\mathrm{p}<0.01$ & $\mathrm{p}<0.01$ & $\mathrm{p}<0.01$ \\
LAP & $\mathrm{p}<0.01$ & $\mathrm{p}<0.01$ & $\mathrm{p}<0.01$ \\
T- B & $\mathrm{NS}$ & $\mathrm{NS}$ & $\mathrm{p}<0.01$ \\
ALB & $\mathrm{p}<0.01$ & $\mathrm{p}<0.01$ & $\mathrm{p}<0.01$ \\
A $/ \mathrm{G}$ & $\mathrm{p}<0.01$ & $\mathrm{NS}$ & $\mathrm{p}<0.01$
\end{tabular}

NS : not significant

表 5. MCV と肝機能検査各項目との相関々係（相関係数 $\mathrm{r}:$ ）

\begin{tabular}{|c|c|c|c|c|c|c|c|c|c|c|c|c|}
\hline & ZTT & GOT & GPT & $\mathrm{OP}$ 比 & $\mathrm{LDH}$ & ALP & $\gamma \mathrm{GTP}$ & $\mathrm{CHE}$ & LAP & $\mathrm{T}-\mathrm{B}$ & ALB & $\mathrm{A} / \mathrm{G}$ \\
\hline 慢性肝炎 & -0.06 & -0.08 & -0.19 & 0.11 & -0.19 & -0.25 & -0.06 & 0.03 & -0.15 & -0.18 & 0.03 & 0.05 \\
\hline $\begin{array}{l}\text { アルコール } \\
\text { 肝 } \mathrm{a}\end{array}$ & 0.38 & 0.38 & $\begin{array}{r}-0.21 \\
(\mathrm{p}\end{array}$ & $\begin{array}{r}0.71 \\
0.01)\end{array}$ & $\begin{array}{c}0.64 \\
p<0.01)\end{array}$ & -0.12 & 0.15 & $\begin{array}{c}-0.71 \\
p<0.01)\end{array}$ & 0.15 & 0.16 & -0.38 & -0.42 \\
\hline $\begin{array}{l}\text { アルコール } \\
\text { 肝b }\end{array}$ & -0.11 & -0.15 & -0.43 & $\begin{array}{r}0.50 \\
0.05)\end{array}$ & 0.07 & 0.32 & 0.18 & 0.01 & 0.10 & 0.20 & -0.32 & 0.03 \\
\hline
\end{tabular}


炎では MCV と有意の相関を認めた項目は皆無であっ た。アルコール肝 a では GOT / GPT(OP 比), LDH, $\mathrm{CHE}$ の 3 項目に有意の相関を認めた。アルコール肝 b では OP 比のみ有意であった。

\section{IV 考察}

アルコール性肝障害は, 過去十数年にわたり増加が 著しく, 今日わが国では肝疾患入院症例の約 1 割に認 められる1)。一方, ウイルス肝炎が風土病的にま儿延し ているわが国では，アルコール性肝障害であっても， 必ずしも純粋にアルコール起因とは判断できないとい ら問題がある。しかし，肝障害の真の原因が何であれ， 领酒歷を有する患者と有しない患者の間の相違点を検 討することは，重要なことと思われる。今回筆者は末 梢血所見の变化を中心に検討した。その結果 MCV の
増大はアルコールの影響を判断する上で，有用な指標 になると思われた。また肝機能検査値の比較でアル コール性肝障害に怙いては, ZTT の増加が有意ではな いことは興味深い。つまり MCVが増加し, ZTTが比 較的低值を示寸症例はアルコール性肝障害の可能性が 高いと思われる。

最後に MCV と各肝機能検查項目との相関関係であ るが，飲酒の影響は MCV に大きく現われてくるので あるから, MCV と有意の相関を有する OP 比, LDH, $\mathrm{CHE}$ は, 肝㵴が飲酒によって影響を受ける本質的な検 査項目であろうと思われる。

\section{文献}

1 ) 武内重五郎, 他：わが国におけるアルコール性肝障害の実態 (その 2 ), 日消誌, $84(8): 1623-1630,1987$

\title{
Study of Hematological Values in Patients with Alcoholic Liver Injury \\ Tetsuo MORIMOTO*, Yukinori OKAZAKI* and Minoru MIZUTA*
}

\begin{abstract}
Hematological values were studied in cases of a thorough physical examination, chronic hepatitis and alcoholic liver injury. Cases of a thorough physical examination were a control group. Only thrombocyte count was decreased in cases of chronic hepatitis as compared with a control group. On the other hand a red blood cell count, $\mathrm{MCV}, \mathrm{MCH}$ and neutrophils were changed significantly in cases of alcoholic liver injury. A red blood cell count was decreased, but $\mathrm{MCV}, \mathrm{MCH}$ and neutrophils were increased. Correlation between $\mathrm{MCV}$ and each item of liver function tests was studied. No significantly correlated item was found in a control group and cases of chronic hepatitis, but GOT/GPT, LDH and CHE were significantly correlated in cases of alcoholic liver injury.
\end{abstract}

* Department of Internal Medicine, Syutow Hospital, Yanai, Japan 